\title{
Pengembangan Geowisata Berbasis Folklore Di Desa Gentan Kecamatan Bulu Kabupaten Sukoharjo
}

\author{
Umi Yuliati $^{1}$, Rara Sugiarti ${ }^{1}$, Tiwuk Kusuma Hastuti ${ }^{1}$, Suryandari Istiqomah ${ }^{2}$, \\ ${ }^{1}$ Fakultas Ilmu Budaya, Universitas Sebelas Maret \\ ${ }^{2}$ Fakultas Ekonomi dan Bisnis, Universitas Sebelas Maret
}

Fahana2008@gmail.com, rarasugiarti@staff.uns.ac.id, tiwuksejarah@gmail.com

\begin{abstract}
Abstrak
Desa Gentan berpotensi untuk dikembangkan menjadi destinasi pariwisata karena memiliki daya tarik geowisata. Potensi wisata yang dimiliki desa Gentan meliputi potensi alam, budaya, sejarah, kuliner, wisata minat khusus maupun wisata buatan. Akan tetapi, potensi tersebut belum dikelola secara optimal. Deretan pegunungan yang melingkupi Desa Gentan adalah bagian Unesco Geopark Gunung Sewu Gunung Kidul-Wonogiri-Pacitan. Gunung dan bukit "batuan memanjang", bahkan folklore lisan Desa Gentan tidak terpisahkan dengan legenda keberadaan Gunung Segendong dan Gunung Sepikul, legenda batu seribu, mitos sendang lele, mitos platar ombo, dan mitos embung pacinan. Folklore sebagian lisan yang berkembang di Gentan yaitu upacara bersih desa, dan folklore bukan lisan meliputi makanan khas (tiwul, bothok mlanding, pecel gendhar), jamu, dan rumah joglo. Tujuan pengabdian yaitu mengembangkan Kawasan Geowisata berbasis folklore yang menitikberatkan pada diversifikasi bentuk dengan menggali potensi alam dan kearifan lokal warga desa. Metode yang digunakan dalam pengabdian ini adalah observasi, diskusi, pelatihan dan pendampingan secara langsung. Kegiatan pengabdian meliputi pelatihan pembuatan storytelling folklore lisan, Pembuatan guide book "Buku Saku Gentan Geopark Village", pendampingan pembuatan paket wisata, pelatihan guiding untuk pemandu lokal, pelatihan pembuatan makanan khas, penataan lokasi atraksi wisata. Kegiatan pengabdian menghasilkan Guide Book "Buku Saku Gentan Geopark Village", paket wisata, storytelling folklor lisan, penambahan atraksi wisata, dan pemberdayaan ekonomi masyarakat dengan terbentuknya Asosiasi Boga Citra Gentan.
\end{abstract}

Kata kunci: geowisata, folklore, Desa Gentan, storytelling

\section{PENDAHULUAN}

1. Latar Belakang

Desa Gentan secara administratif termasuk dalam wilayah Kecamatan Bulu, Kabupaten Sukoharjo, Jawa Tengah. Letak Desa Gentan berada di wilayah paling Selatan Kota Sukoharjo dan berbatasan langsung dengan Kecamatan Selogiri Kabupaten Wonogiri. Berjarak $2 \mathrm{~km}$ dari ibukota kecamatan dan 1 jam perjalanan dari ibukota
Kabupaten. Luas wilayah Desa Gentan yaitu 457.713 ha, yang terdiri dari 79.728 ha lahan persawahan tadah hujan dengan tingkat kesuburan sedang, 124 ha lahan tidak subur/kritis (tidak diolah dan dibiarkan tumbuh ilalang karena adanya serangan dari kera hutan), 135.000 ha adalah tanah hutan negara, sisanya digunakan sebagai pemukiman penduduk yang tersebar di 9 RW dan 22 RT (Umi Yuliati, et.al, 2019). Kondisi tanah 
yang kurang subur dan kurang produktif tersebut mendorong masyarakat Desa Gentan merantau ke kota-kota besar untuk bekerja di Jakarta dan bandung.

Secara ekonomi, Desa Gentan termasuk salah satu dari enam kecamatan di Wilayah Kabupaten Sukoharjo yang tingkat perkembangan ekonominya rendah (eprints.ums.ac.id). Tingkat kemiskinan cukup tinggi, di Desa Gentan mencapai 1/3 dari total penduduk (4265 jiwa). Kondisi ini berpengaruh juga terhadap tingkat pendidikan. Angka buta huruf di Desa Gentan mencapai 1458 orang (tidak sekolah/tidak lulus SD) dan 1418 orang berpendidikan dasar lulus SD/SMP (RPJMDesa Gentan 2012-2018).

Meskipun lahan dan kondisi penduduk dalam kategori kurang produktif, akan tetapi secara sosial budaya masyarakat Gentan sangat kuat memegang teguh kebersamaan dan gotong royong. Bahkan bagi warga yang menjadi perantau masih kuat ikatan emosionalnya dengan desa mereka. Agenda tahunan berupa "acara bersih desa" dijadikan ajang untuk berkumpul dan menyumbangkan sebagian penghasilan mereka untuk pembangunan desa. Sementara kondisi wilayah Desa Gentan yang berupa bukit dan pegunungan tersebut ternyata memiliki panorama geopark yang indah Umi Yuliati, et. al, 2019).

Potensi alam dan warisan budaya masyarakat Desa Gentan merupakan daya tarik yang luar biasa dari sudut pandang pariwisata Adat budaya dan kondisi sosial masyarakat menyimpan banyak hal yang dapat menarik wisatawan untuk berkunjung ke Desa Gentan. Warisan budaya yang masih berkembang di Desa Gentan berupa Folklore khususnya yang berupa mitos dan legenda. Mitos dan legenda ini dapat dijadikan landasan dalam mengembangkan geowisata di Desa Gentan.Mitos dan legenda tersebut perlu dikemas sehingga menarik wisatawan. Pengembangan geowisata ini dilakukan dengan memberdayakan warisan folklore yang berkembang di Desa Gentan. Kajian pengembangan geowisata yang berbasis folklore khususnya mitos, legenda, cerita-cerita lokal dan kearifan lokal belum banyak dieksplorasi, sehingga hal ini merupakan peluang bagi pengembangan geowisata di Desa Gentan.

\section{Permasalahan Mitra}

Desa Gentan memiliki potensi untuk dikembangkan menjadi destinasi pariwisata karena memiliki bentang alam yang indah dan didukung dengan folklore yang berkembang dalam masyarakat. Namun, potensi geowisata tersebut belum dikelola secara optimal. Berdasarkan hasil pemetaan Tim Pengabdian, permasalahan yang dihadapi mitra antara lain: (a) SDM di Desa Gentan belum memiliki keahlian dan kurang percaya diri untuk mengembangkan pariwisata; (b) Masyarakat belum menyadari bahwa sumber daya alam dan budaya di tempat tinggalnya memiliki potensi untuk dikembangkan menjadi destinasi wisata. Banyak folklore berupa mitos, legenda, arsitektur dan kuliner belum dikemas menjadi daya tarik wisata; (c) Pengelolaan atraksi wisata belum optimal, Araksi wisata yang dikelola oleh karang taruna hanya Gunung Sepikul dan Sendang Lele, sementara potensi wisata yang lainnya belum dikelola; (d) Pada setiap atraksi wisata belum memiliki pemandu (guide) lokal, mereka yang menjaga parkir terkadang berperan sebagai guide dengan bekal pengetahuan seadanya tentang obyek wisata.

\section{Tujuan Kegiatan}

Kegiatan pengabdian ini bertujuan untuk mengembangkan Kawasan Geowisata berbasis folklore yang menitikberatkan pada diversifikasi bentuk dengan menggali potensi alam dan kearifan lokal warga desa

\section{METODE}

Di dalam mengembangkan Geowisata Desa Gentan Berbasis Folklore, Tim Pengabdian melibatkan masyarakat dalam setiap tahapan dan proses pelaksanaannya. Tahap pertama meliputi observasi potensi sumber daya alam, warisan budaya, folklore yang berkembang dalam masyarakat, dan atraksi wisata. Observasi dilakukan dengan pendekatan yang mengutamakan partisipasi dan keterlibatan masyarakat.

Metode kegiatan diimplementasikan dalam kegiatan pengabdian ini meliputi serap aspirasi, diskusi, pelatihan, operasional kerja, dan pendampingan secara langsung.

Tim Pengabdian menggali folklore yang berkembang dalam masyarakat melalui wawancara.

Ekonomi, Sosial, dan Budaya

991 
Dari hasil wawancara kemudian folklore didentifikasi dan dikelompokkan menjadi folklore lisan, sebagian lisan dan bukan lisan. Kemudian Tim Pengabdian membuat story telling, dan guide book yang berisi potensi wisata dan folklore yang berkembang di Desa Gentan. Tim Pengabdian juga memberikan pelatihan pembuatan story telling dan pemandu wisata dan menambahkan atraksi wisata berbasis pada pada folklore.

Potensi alam dan budaya masyarakat Desa Gentan merupakan daya tarik yang luar biasa dari sudut pandang pariwisata. Beberapa permasalahan yang berkaitan dengan pengelolaan potensi wisata di Desa Gentan menjadi dasar dilakukannya pengabdian ini. Mulai dari kemampuan sumber daya manusia hingga manajemen objek dan atraksi wisatanya.

Metode serap aspirasi digunakan dalam kegiatan sarasehan bersama masyarakat Desa Gentan. Kegiatan tersebut bertujuan menjaring opini masyarakat terkait rencana pengembangan kawasan wisata di Desa Gentan. Kegiatan yang dihadiri oleh seluruh perangkat desa, karang taruna, BABINSA, pedagang, pemilik rumah joglo, tetangga desa, dan PEMDA Sukoharjo ini berjalan dengan lancar dan menghasilkan kesimpulan bahwa seluruh pihak mendukung ide pengembangan wisata di Desa Gentan.

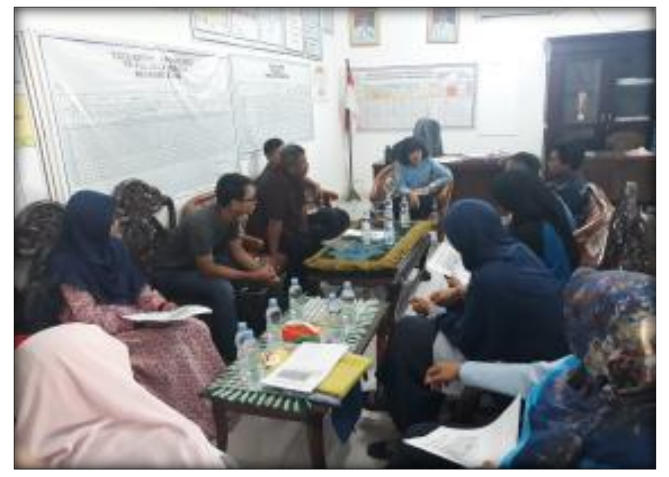

Gambar 1. Rapat Koordinasi untuk memulai pengabdian

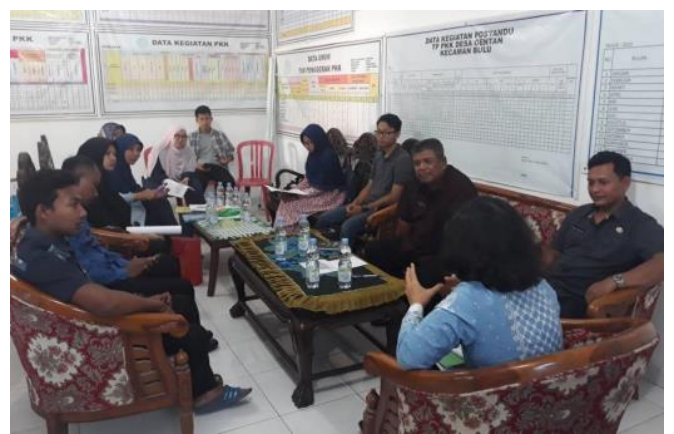

Gambar. 2 Diskusi Tim Pengabdian dengan Mitra

Metode penyuluhan diterapkan dalam kegiatan manajemen Sumber Daya Manusia, meliputi pelatihan pelayanan pariwisata, pelatihan guiding, dan pelatihan pembuatan story telling. Sementara metode pendampingan diterapkan dalam pembuatan paket wisata, pembuatan makanan khas desa Gentan, penataan kawasan atraksi wisata, pembuatan sarana promosi wisata.

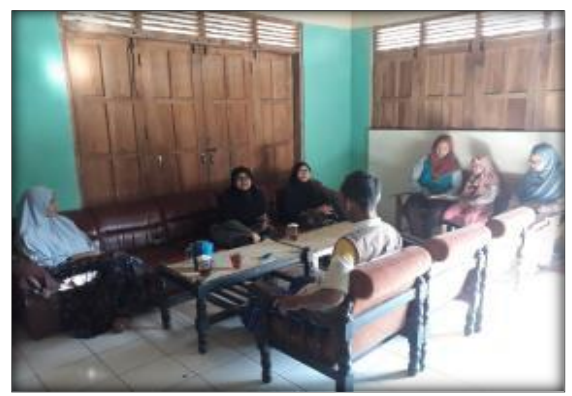

Gambar.3. Wawancara dengan masyarakat untuk menggali folklore

\section{HASIL DAN PEMBAHASAN}

\section{Potensi Geowisata di Desa Gentan}

Hasil observasi menunjukkan bahwa Desa Gentan memiliki potensi wisata yang dapat menarik wisatawan, namun potensi tersebut belum seluruhnya di kelola dengan baik oleh masyarakat Desa Gentan. Potensi tersebut antara lain:

a. Gunung Sepikul. Di tempat ini terdapat beberapa gundukan batu besar yang merupakan lelehan magma gunung merapi purba, yaitu Watu Jaran, Watu Kandang, Watu Tinggik, Watu Pawon, dan Watu Tumpuk.

b. Gunung Segendong. Letaknya berhadapan dengan Gunung Sepikul dan jenis batuannya adalah batu padas, ini berbeda dengan gunung lainnya yang berupa batu kapur.

$$
\text { Ekonomi, Sosial, dan Budaya }
$$




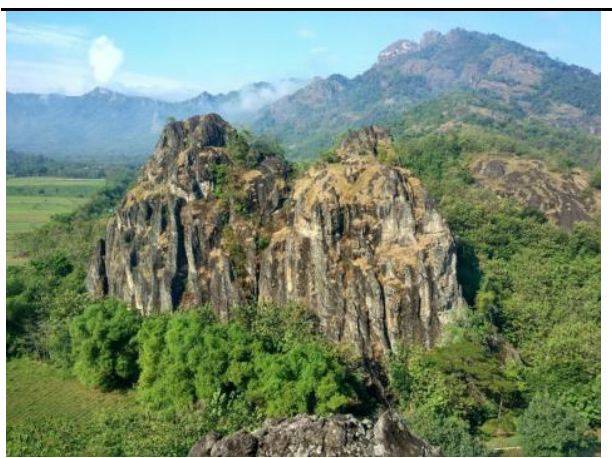

Gambar 4. Gunung Sepikul dan Segendong

c. Hutan Pecinan. Hutan ini berada di pinggiran Desa Gentan, berseberangan dengan pemukiman penduduk. Selain suasana hutan, setiap pagi akan terlihat pemandangan segerombolan kera hutan yang turun gunung untuk mencari makanan.

d. Sendang Lele. Di tempat ini terdapat sumber air pegunungan yang tidak pernah kering dan terus mengalir. Penduduk desa mempertahankan keberadaan sumber air tersebut dengan membuatkan kubangan yang disebut sendang dan didalamnya diisi dengan ikan lele yang sudah berumur tahunan.

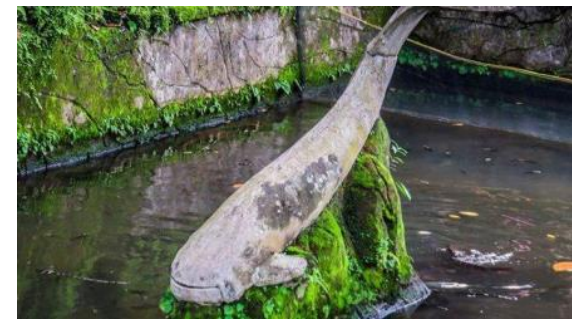

Gambar 5. Sendang lele

e. Embung Sebo Menggolo. Tempat ini sudah dibangun dan dilengkapi dengan DAM pengatur air. Selama ini selain sebagai tempat tampungan air dari sungai, embung tersebut belum dimanfaatkan.

f. Bumi Perkemahan Batu Seribu. Tempat ini dibangun tahun 1990-an dan mampu menampung lebih dari 500 peserta kemah. Akan tetapi saat ini kondisinya tidak terawat .

g. Rumah Joglo. Banyak rumah berbentuk joglo yang sudah kosong karena ditinggalkan pemiliknya. Beberapa diantaranya masih terawat tetapi pemiliknya bertempat tinggal di luar kota.

h. Makam kyai Bas. Sebagai cikal bakal Desa Gentan.

i. Makanan tradisional yaitu tiwul, bothok mlandhing dan pecel gendhar

j. Platar Ombo
Platar Ombo dan Watu Abang adalah sebuah bukit yang terletak di tengah antara gunung Sepikul dan Gunung Segendong. Selama ini, bukit Platar Ombo jarang dikunjungi warga karena tersebar mitos adanya Ular besar atau Kera penunggu bukit tersebut. Berdasarkan hasil observasi yang dilakukan oleh tim dan pengurus Pokdarwis, bukit ini sangat indah dan memiliki view yang mampu menyuguhkan atraksi alam yang luar biasa. Dari tempat yang sama, pengunjung dapat melihat sunrise di pagi hari dan sunset di sore hari. Sementara Watu Abang, merupakan pemandangan yang dapat dilihat di pagi atau sore hari dari gunung Pecinan yang terletak berdampingan dengan bukit Platar Ombo. Bebatuan di Gunung Pecinan tampak merah ketika terkena sinar matahari.
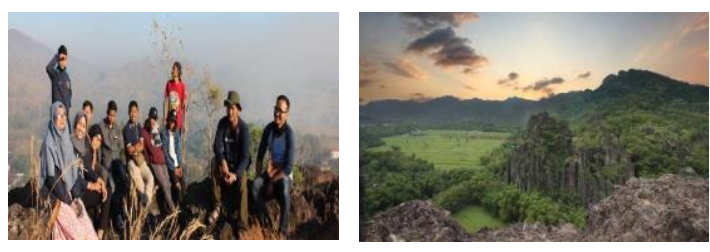

Gambar 6. Pendakian di Platar Ombo

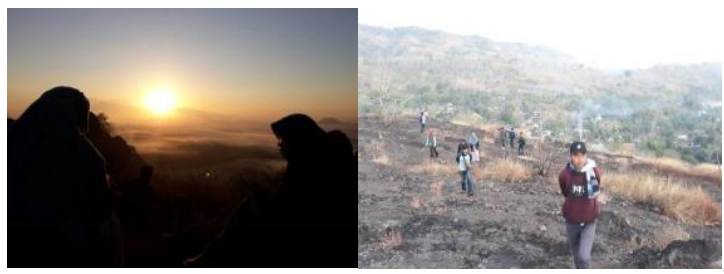

Gambar 7. Sunrise di Platar Ombo

k. Embung Pacinan merupakan sebuah penampungan air yang bersumber dari atas Gunung Pacinan yang tidak pernah kering airnya.

1. Batu Seribu Pacinan. Batu Seribu Pacinan merupakansalah satu objek wisata yang terletak di Desa Gentan, namun berada dalam wilayah konservasi Perhutani. Objek wisata ini terdiri dari taman bermain anak-anak dan objek wisata kolam renang dengan sumber air dari deretan Gunung Seribu.

2. Folklore di Kawasan Geowisata Desa Gentan 
Folklore merupakan cabang ilmu antropologi yang mempelajari tentang kebudayaan di suatu masyarakat yang telah diwariskan secara turuntemurun (Amanat, 2019: 69). Berdasarkan tipenya folklore dapat dikelompokkan menjadi tiga yaitu: folklore lisan, folklore sebagian lisan, dan bukan lisan (Danandjaja, 2007: 21-190). Folklor adalah sebagian kebudayaan kolektif, yang tersebar dan diwariskan secara turun-temurun, di antara kolektif secara tradisional dalam versi yang berbeda, baik dalam bentuklisan maupun contoh yang disertai dengan gerak isyarat atau alat pembantu pengingat (mnemonic device) (Endraswara, 2013: 2)

Potensi folklore yang berkembang di Desa Gentan yang dapat dimanfaatkan untuk pengembangan geowisata yaitu: (a). folklor lisan berupa legenda, mitos, cerita rakyat; (b). folklor sebagian lisan berupa upacara tradisional dan pesta rakyat tradisional (upacara bersi desa dan upacara kuras sendang lele), dan (c). folklore bukan lisan meliputi makanan tradisional, jamu, dan arsitektur bangunan tradisional berupa rumah joglo. Folklore yang berkembang berhubungan erat dengan bentang alam di Desa Gentan berupa gunung. Folklore yang dimiliki masyarakat Desa Gentan tersebut dapat dijadikan pijakan dalam pengembangan destinasi wisata, yaitu pengembangan geowisata.

a. Mitos Sendang Lele.

Sendang lele merupakan kolam lele yang telah ada sejak puluhan bahkan ratusan tahun yang lalu. Awalnya sendang lele merupakan kolam yang digunakan untuk memandikan kerbau-kerbau yang dimiliki oleh masyarakat desa sekitar atau istilah jawanya adalah "geruman". Di dalam geruman ini kerbau-kerbau berendam atau dimandikan dan ketika naik ke atas terdapat banyak lintah yang menempel pada kerbau-kerbau tersebut. Menurut ceita masyarakat Desa Gentan, fungsi tersebut berubah setelah pada suatu sore menjelang magrib terdengar bunyi gemuruh, terdapat beberapa orang melihat dari arah kreteg Ngrodok mereka melihat seekor ular besar dan dibelakangnya diikuti oleh ikan-ikan menuju arah selatan, kemudian keesokan harinya, sendang yang selama ini menjadi geruman tadi sudah terdapat lele-lele yang tinggal di sendang tersebut.
Pada awalnya Sendang Lele diisi oleh lele-lele asli dari Sendang Lele, yang salah satunya terdapat lele dengan bentuk kepala dan duri saja. Menurut cerita masyarakat setempat tidak semua orang dapat melihat atau diperlihatkan bentuk lele tersebut. Pada bulan Suro masyarakat desa Baseng melakukan kuras sendang bersamaan dengan kegiatan rasulan atau bersih dusun. Dalam kegiatan kuras sendang, tokoh masyarakat akan menyatakan rencana tersebut di depan sendang atau dalam istilah masyarakat setempat diobong-obongi, maka keesokan harinya saat kuras sendang jumlah lele yang ada di sendang hanya sekitar $25 \%$ dari jumlah total lele yang selama ini kelihatan di Sendang Lele. Setelah pengurasan sendang, maka lele yang telah diangkat tadi dikembalikan lagi ke sendang lagi dan keesokan harinya didapati jumlah lele yang lebih banyak daripada jumlah lele yang telah diangkat pada saat acara kuras sendang tersebut. Masyarakat setempat meyakini $75 \%$ lele yang ada telah masuk ke rumpon-rumpon di bawah pohon yang ada di sendang lele tersebut. Cerita tentang sendang lele dengan lele berbentuk kepala dan duri saja mengundang banyak wisatawan untuk mengunjungi sendang lele.

Bagi masyarakat desa sekitar terdapat beberapa hal yang ditabukan ketika berada di Sendang Lele, salah satunya berkata kotor atau berkata tidak baik. Jika terdapat seseorang yang melanggar atau dengan sengaja berkata kotor di Sendang Lele maka akan berdampak langsung kepada orang yang berkata kotor tersebut, seperti pingsan, masuk angin atau mati suri. Bahkan pada jaman dahulu, bagi masyarakat sekitar menunjuk Sendang Lele dengan jari telunjuk ke Sendang Lele merupakan hal yang ditabukan.

\section{b. Legenda Gunung Sepikul dan Segendong}

Selain Sendang Lele, wisata alam unggulan lainnya adalah Gunung Sepikul dan Gunung Segendong yang berada di dua desa yaitu Desa Tiyaran dan Desa Gentan Kecamatan Bulu Kabupaten Sukoharjo. Gunung Sepikul merupakan bukit batu yang berjumlah dua dengan bentuk yang sejajar dan tinggi yang hampir sama. Sedangkan Gunung Segendong merupakan satu gundukan bukit besar yang berdekatan dengan Gunung Sepikul. Nama Gunung Sepikul dan Gunung Segendong ini berdasarkan pada cerita rakyat secara turun-

$$
\text { Ekonomi, Sosial, dan Budaya }
$$


temurun. Terdapat dua versi cerita yang berkembang dalam masyarakat desa atas terjadinya Gunung Sepikul dan Gunung Segendong. Versi pertama dihubungkan dengan legenda pembuatan Candi Prambanan dan Versi Kedua dihubungkan dengan pembangunan Gunung Seribu.

Versi pertama Gunung Sepikul dikaitkan dengan legenda berdirinya Candi Prambanan. Menurut legenda, kerajaan Prambanan yang dipimpin oleh Ratu Boko diserang Kerajaan Pengging yang diimpin oleh Bandung Bondowoso. Di dalam peperangan tersebut Ratu Boko tewas di tangan Bandung Bondowoso dan Bandung Bondowoso menguasai Kerajaan Prambanan. Ratu Boko mempunyai putri yang cantik jelita yaitu Roro Jonggrang. Ketika melihat Roro Jonggrang, Bandung bondowoso terpikat dan jatuh cinta kepada Roro Jonggrang. Untuk menjaga keluarga dan rakyatnya, Roro Jonggrang menerima lamaran Bandung Bondowoso dengan satu syarat dibuatkan seribu candi dalam satu malam. Bandung Bondowoso yang memiliki pasukan jin menyanggupi syarat tersebut. Dalam waktu satu malam pasukan jin telah berhasil membangun candi-candi dan jumlahnya hampir mendekati seribu, melihat hal tersebut, Roro Jonggrang memerintahkan dayang-dayang dan masyarakat untuk membakar jerami dan menumbuk padi di lesung sehingga ayam berkokok yang menandakan hari telah pagi. Melihat cahaya kuning kemerahan, bunyi lesung dan ayam berkokok, jin-jin mengira hari telah pagi sehingga mereka serta-merta berhenti membangun candi tersebut. Jin yang tengah lewat di Dusun Baseng yang membawa pasokan batu-batu untuk membangun candi juga berhenti dan meletakkan begitu saja batu-batu tersebut. Batu tersubut dibawa dengan cara dipikul dan digendong sehingga menjadi Gunung Sepikul dan Segendong.

Versi kedua, yaitu versi Gunung Seribu. Gunung Sepikul terjadi karena adanya para "wali atau raksasa atau jin" yang memiliki kesaktian mandraguna sedang lewat memikul batu dan menggendong batu besar untuk memindahkan batubatu tersebut ke deretan Gunung Seribu. Masyarakat percaya bahwa pemindahan batu-batu besar tersebut dibawa atau dipikul dengan batang pohon kelor. Namun pada tengah malam ketika melewati Dusun Baseng mereka mendengar suara orang menumbuk padi. Para Wali tersebut mengira bahwa mereka hari telah pagi sehingga meninggalkan batu yang mereka bawa begitu saja di kawasan tersebut dan keesokan harinyamuncullah Gunung Sepikul dan Segendhong. Para Wali atau raksasa menganggap perjalanan mereka diganggu oleh para penduduk sehingga mereka mengucapkan sumpah "yen durung jambul uwanen durung payu rabi". Sedangkan apa yang dilakukan oleh penduduk tersebut sebenarnya tidaklah dilakukan secara sengaja untuk mengganggu para Wali yang sedang lewat, namun mereka menumbuk padi pada malam hari untuk mempersiapkan perbekalan atau sarapan pada pagi hari sebelum pergi ke sawah. Oleh karena mereka takut kesiangan, maka mereka memulai menumbuk padi pada malam hari dan mereka tidak tahu kalau para wali sedang lewat membawa gunung dan tidak sengaja menganggu pemindahan gunung tersebut.

\section{c. Mitos Platar Ombo}

Platar Ombo Desa Gentan merupakan plataran yang berada di Daataran tinggi yang berada yang berada di sekitar deretan gunung-gunung yang ada di Desa Gentan. Pemandangan di Platar Ombo pada pagi hari terlihat view yang indah, dari sebelah timur terlihat sunrise serta Gunung Lawu dan Gunung Kelud. Dari sisi barat terlihat Gunung Merapi dan Gunung Merbabu. Di Platar Ombo juga terlihat view Gunung Sepikul dan Gunung Segendong dengan sangat jelas. Mitos yang berkembang dalam masyarakat tentang Platar Ombo, masyarakat percaya bahwa Platar Ombo merupakan tempat pertemuan atau rapat atau terminal para jin atau makhluk gaib yang dilaksanakan pada hari-hari yang dianggap sakral oleh masyarakat Jawa, yaitu setiap malam Selasa Kliwon dan malam Jumat Kliwon. Masyarakat Desa Gentan percaya bahwa di atas bukit Platar Ombo terdapat ular naga dan kera penunggu.

\section{Pengembangan Geowisata di Desa Gentan}

Geowisata Gentan merupakan salah satu desa wisata di Desa Gentan, Kcamatan Bulu, kabupaten Sukoharjo jawa Tengah. Geowisata Gentan ini merupakan Desa Wisata dengan pendekatan konsep wisata alam dari warisan alam yang terbentuk jutaan tahun yang lalu. Di desa Gentan terdapat beberapa objek wisata menarik baik secara fisik yaitu bentukan alam maupun secara cerita atau sejarah yang menyertai pada objek-objek tersebut.

Deretan pegunungan yang melingkupi Desa Gentan adalah bagian UNESCO GEOPARK

$$
\text { Ekonomi, Sosial, dan Budaya }
$$


GUNUNG SEWU Gunungkidul-Wonogiri-Pacitan. Gunung dan bukit "batuan memanjang" yang mengelilingi perkampungan penduduk begitu menyatu dengan kehidupan. Bahkan legenda Desa Gentan tidak terpisahkan dengan keberadaan Gunung Sepikul dan Segendong. (RPJMDes Desa Gentan tahun 2012-2018). Pemukiman penduduk yang terpisah-pisah oleh bukit justru memberi nilai lebih bagi Desa Gentan. Keberadaan kera liar yang ada dipinggir hutan, ternyata menjadi daya tarik tersendiri dan wargapun cenderung membiarkan kawanan kera tersebut yang terlihat menyatu dengan lingkungan di sana.

Pengembangan geowisata dititikberatkan pada diversifikasi bentuk dengan menggali potensi alam yang ada serta kearifan lokal warga desa yang masih ada. geowisata merupakan konsep pemanfaatan sumber daya alam yang bertujuan untuk perlindungan alam. Konsep geowisata tidak bisa dilepaskan dari dua konsep yang lainnya yaitu ekowisata (ecotourism) dan taman bumi (geopark). Geowisata merupakan konsep yang diterapkan di Desa Gentan dengan mengintegrasikan seluruh sumber daya alam di sekitar lokasi yang memiliki keunikan geologi untuk mewujudkan kesejahteraan masyarakat melalui pengembangan ekonomi kreatif bersumber dari alam dan budaya yang ada (Roni Permadi: 2018).

Pengembangan geowisata berbasis folklore dilakukan dengan menggali khasanah budaya lokal yang berupa folklor lisan melalui obsevasi dan wawancara. Kemudian dibuat kategorisasi berdasarkan ada tidaknya nilai baik yang berwujud (tangible) maupun yang tidak berwujud (intangible) dan diklasifikasikan berdasarkan nilai religius, mitologis atau historis sebaga upaya pembentukan citra sehingga memiliki daya jual. Tim Pengabdian melakukan identifikasi folklore yang akan dijadikan tema dan trademark destinasi wisata. Folklor lisan kemudian dikonkritkan dan diselaraskan dengan lanskap di sekitarnya sehingga dapat dinikmati secara inderawi oleh pengunjung (Amanat, 2019: 71). Seperti di Sendang lele dikonkretkan secara visual dengan patung lele yang berada di Sendang. Agar wisatawan dapat dapat menikmati keberadaannya dalam narasi cerita rakyat yang ingin dinikmatinya maka dibuat storry telling dan guide book. Dalam upaya untuk mengembangkan geowisata berbasis folklore di Desa Gentan, Tim Pengabdian melakukan kegiatan sebagai berikut:

a. Pembuatan storry telling dan guide book, agar wisatawan dapat dapat menikmati keberadaannya dalam narasi cerita rakyat yang ingin dinikmatinya maka dibuat storry telling dan guide book.

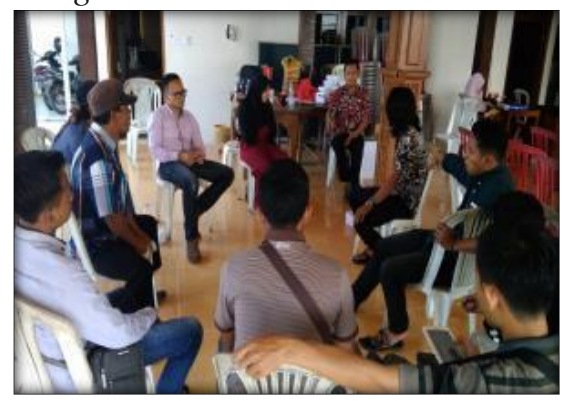

Gambar 8. Pelatihan Guiding dan pembuatan Story Telling

b. Aktifitas promosi wisata di Desa Gentan ditempuh dengan beberapa langkah, antara lain pembuatan paket wisata, pembuatan branding Desa Wisata dengan nama Gentan Geopark Village. Branding memiliki tujuan untuk meningkatkan kualitas brand sebuah destinasi wisata. Teknik promosi dengan membuat brosur, leaflet, dan pameran-pameran dinilai kurang maksimal dalam menarik minat wisatawan. Pada saat wisatawan mencari informasi tentang destinasi wisata yang menarik, disinilah peran destination branding. Melalui strategi branding akan mampu mempromosikan, membangun citra, memberikan gambaran dan paparan destinasi tujuan (Ariando, Valdo : 2015, hlm. 132).

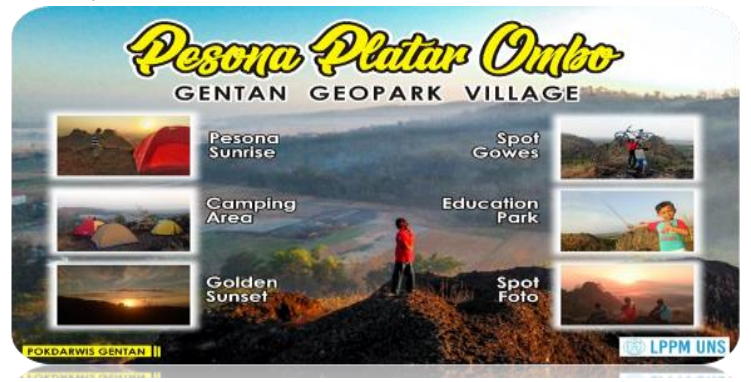

Gambar 9. . Paket wisata Pesona platar Ombo 


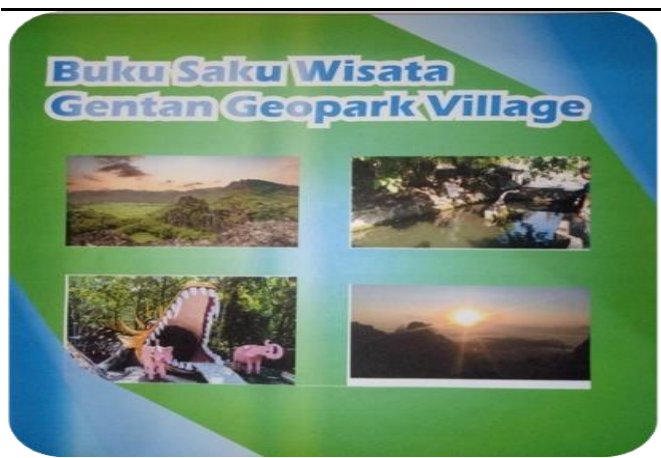

Gambar 10. Guide Book "Gentan Geopark Village"

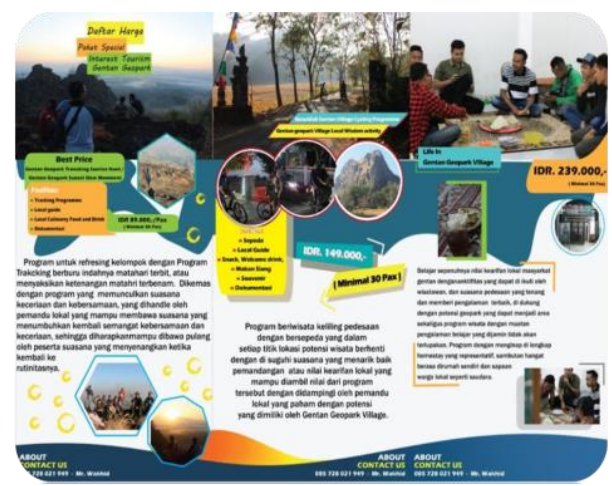

Gambar 11. Paket wisata Gentan Geopark Village

c. Pembuatan jalur geotrack. Selain akses jalan pendakian, perlu adanya papan peraturan atau SOP bagi wisatawan yang berkunjung ke Platar Ombo, karena medan yang cukup terjal, sering terjadi kebakaran lahan, dan upaya menjaga kelestarian alam. Tujuan lain dari optimalisasi Platar Ombo adalah mengemas mitos yang beredar di masyarakat bahwa di atas bukit terdapat Ular Naga dan Kera penunggu, yang sering membuat masyarakat desa sering resah. Sehingga terkadang muncul tindakan-tindakan warga yang tidak terduga, misalnya membakar lahan dengan dalih ingin membunuh Ular penunggu yang mereka jumpai.

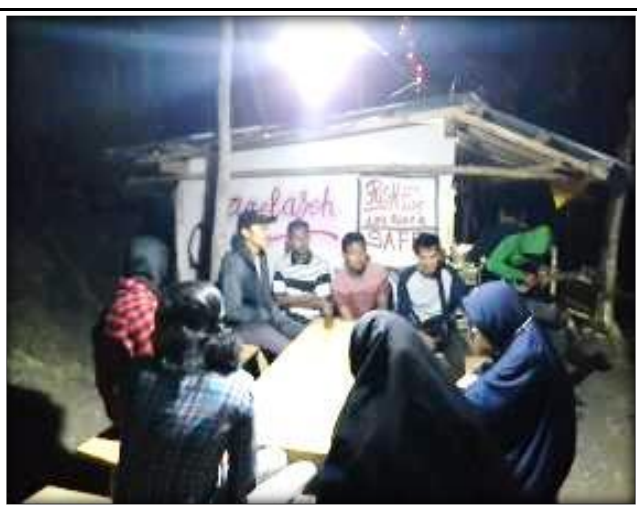

Gambar.12 Diskusi malam untuk pembuatan jalur geotrack

d. Melakukan manajemen atraksi wisata, meliputi dibukanya lokasi wisata yang baru yaitu Platar Ombo dan Watu Abang, menata lokasi wisata (Platar Ombo, Sendang Lele dan Embung Pacinan), mengangkat makanan lokal sebagai ikon desa Gentan yang dikelola oleh Asosiasi Boga Citra Gentan dan membuat souvenir "Gentan Geopark Village" berupa kaos yang didesain oleh warga desa.
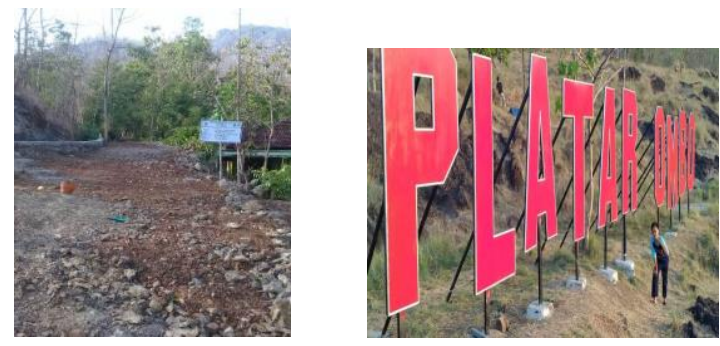

Gambar. 13. Kondisi Platar Ombo Sebelum dan setelah pengabdian
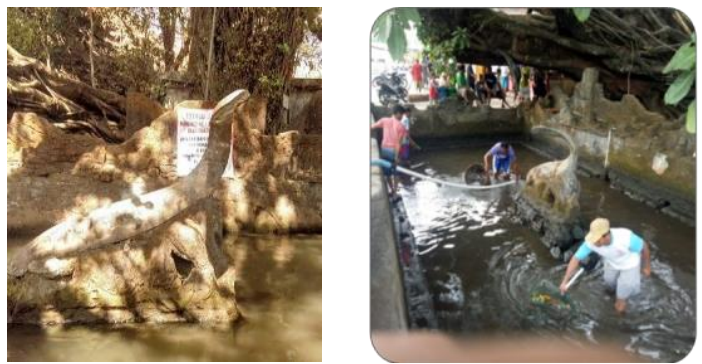

Gambar 14. Kondisi Sendang Lele sebelum dan sesudah pengabdian 

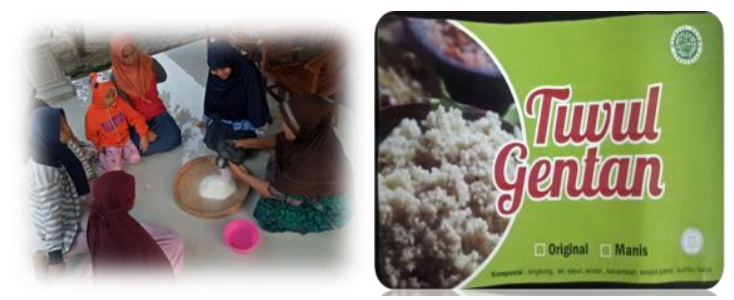

Gambar 15. Pelatihan pembuatan tiwul.

e. Pemanfaatan teknologi informasi dengan memanfaatan fasilitas di media sosial diharapkan akan semakin mempermudah wisatawan untuk menemukan kawasan wisata di Desa Gentan. Media sosial yang di pilih adalah instagram dengan alamat gentan_geoparkvillage dan pembuatan titik map di google https://www.google.com/maps/place/Platar+Om bo+Gentan+Geo+Park+Village, https://www.google.com/maps/place/Embung $+\mathrm{G}$ entan, dan

https://www.google.com/maps/place/Sendang+K i+Truno+Lele, dan Pembuatan akun di channel youtube PESONA GENTAN GEOPARK VILLAGE url: https://youtu.be/3GO3elAhF0Y

f. Pembuatan sarana amenitas, yaitu tersedianya papan informasi wisata dan pembuatan profil wisata Desa Gentan

g. Pembangunan sarana aksesibilitas berupa pembuatan gapura, pembuatan papan nama lokasi wisata, pembuatan papan penunjuk arah, dan peta wisata Desa Gentan.

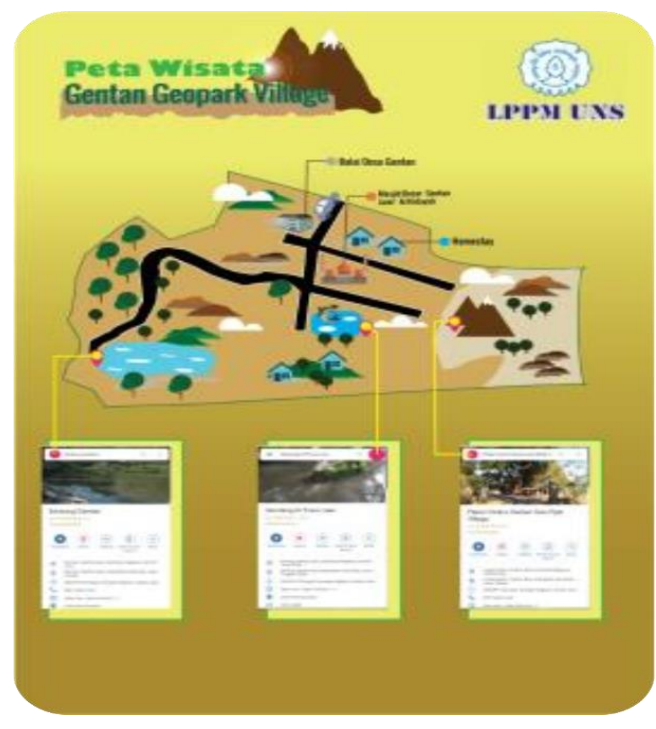

Gambar 16. Peta wisata Desa Gentan

\section{KESIMPULAN}

Pengembangan geowisata berbasis folklore berupa mitos, legenda, cerita-cerita lokal yang didasarkan pada karakteristik budaya akan memiliki manfaat bagi masyarakat pendukungnya. Warisan budatya tersebut akan bermanfaat dan dimanfaatkan oleh masyarakat Desa Gentan. Pengembangan Geowisata Desa Gentan berbasis folklore, bukan hanya berdampak bagi kepuasan wisatawan dan pelaku pariwisata saja, melainkan juga bagi masyarakat lokal. Dampak yang dapat dirasakan masyarakat lokal antara lain peningkatan pendapatan akibat dari transaksi ekonomi dalam kegiatan geowisata di Desa Gentan. Meningkatnya pendapatan ekonomi, maka secara tidak langsung juga meningkatkan kesejahteraan dan kualitas kehidupan mereka. Banyaknya wisatawan yang datang berkunjung ke desa-desa wisata juga akan memberikan dampak positif bagi pelaku bisnis pariwisata karena meningkatnya pasar konsumen dan peminat akan sebuah destinasi wisata. Pengembangan geowisata berbasis folklore berdampak bagi pelestarian tradisi dan budaya dalam kehidupan masyarakat, sehingga potensi dan kearifan lokal yang ada dapat terus dipertahankan. Pengembangan geowisata Ekonomi, Sosial, dan Budaya 998 
berbasis folklore juga menjadi sarana konservasi alam dan lingkungan hidup yang konkrit.

\section{REFERENSI}

Ariando, Valdo. 2015. Destination Branding Kepulauan Seribu: Studi Kasus Destination Branding Kepulauan Seribu Dalam Upaya Mengembangkan Destinasi Wisata Bahari Internasional Diunduh dari http://etd.repository.ugm.ac.id.

Data Statistik Profil Wisatawan Wisnus 2016

James Danandjaja. 2007. Folklor Indonesia Ilmu

Gosip, Dongeng, dan lain-lain. Jakarta: Pusata Utama Grafiti.

Manafe, Janri D. dkk., "Pemasaran Pariwisata Melalui Strategi Promosi Objek Wisata Alam, Seni Dan Budaya : Studi Kasus Di Pulau Rote" dalam Jurnal Bisnis dan Manajemen Islam. Vol. 4. No. 1. Juni 2016. Hlm. 101-123. http://journal.stainkudus.ac.id

LKjIP Kabupaten Sukoharjo Tahun 2017

RPJMDesa Gentan 2012-2018

Roni Permadi . 2018. Peran geopark nasional rinjani dalam mendukung Pengembangan ekowisata, geokonservasi dan Geowisata. http://ftgeologi.unpad.ac.id

sukoharjokab.bps.go.id. diakses 3 Agustus 2018

Suwardi Endraswara (ed.), 2013. Folklor Nusantara Hakikat, Bentuk, dan Fungsi. Yogyakarta:

\section{Penerbit Ombak}

Suwardi Endraswara et.al. (eds.). 2013. Folklor dan Folklife Dalam Kehidupan Dunia Modern. Yogyakarta: Penerbit Ombak.

Tiwuk K Hastuti, Umi Yuliati. 2017. "Model Pengembangan Ekowisata Hutan Mangrove Berbasis Penguatan Kelembagaan tradisional di Kabupaten Bantul". Laporan Penelitian. Surakarta: LPPM UNS

Umi Yuliati, Tiwuk K Hastuti. 2015. Model Pengembangan Wisata Budaya Di Kota Surakarta. Laporan Penelitian. Surakarta: LPPM UNS

Tri Amanat.. 2019. "Strategi Pengembangan Destinasi Wisata Berbasis Folklor (Ziarah Mitos: Lahan Baru Pariwisata Indonesia)" dalam Jurnal Pariwisata Terapan, Vol 3, No 1, 2019. https://doi.org/10.22146/jpt.48836.

Umi Yuliati. et. al. 2019. "PPUD Pengembangan Geowisata Berwawasan Edukasi dan Kearifan Lokal di Desa Gentan Kecamatan Bulu Kabupaten Sukoharjo". Laporan Pengabdian Kepada Masyarakat. Surakarta: LPPM UNS.

Umi Yuliati, Tiwuk K Hastuti. 2015. Model Pengembangan Wisata Budaya Di Kota Surakarta. Laporan Penelitian. Surakarta: LPPM UNS 